\title{
Cloning, Expression, and Characterization of a Novel GH-16 $\beta$-Agarase from Agarivorans sp. JA-1
}

\author{
Myong Je Jeon, A-Ram Kim, Dong-Geun Lee and Sang-Hyeon Lee* \\ Department of Pharmaceutical Engineering, College of Medical Life Sciences, Silla University, Busan 617-736, Korea
}

Received October 23, 2012 /Revised November 9, 2012 / Accepted November 14, 2012

\begin{abstract}
Authors report the glycoside hydrolase (GH) family 16 -agarase from the strain of Agarivorans sp. JA-1, which authors previously stated as recombinant expression and characterization of GH-50 and GH-118 $\beta$-agarase. It comprised an open reading frame of 1,362 base pairs, which encodes a protein of 49,830 daltons consisting of 453 amino acid residues. Valuation of the total sequence showed that the enzyme has $98 \%$ nucleotide and $99 \%$ amino acid sequence similarities to those of GH-16 $\beta$-agarase from Pseudoalteromonas sp. CY24. The gene corresponding to a mature protein of 429 amino acids was recombinantly expressed in Escherichia coli, and the enzyme was purified to homogeneity by affinity chromatography. It showed maximal activity at $40^{\circ} \mathrm{C}$ and $\mathrm{pH} 5.0$, representing $67.6 \mathrm{units} / \mathrm{mg}$. Thin layer chromatography revealed that mainly neoagarohexaose and neoagarotetraose were produced from agarose. The enzyme would be valuable for the industrial production of functional neoagarooligosaccharides.
\end{abstract}

Key words : $\beta$-agarase, glycoside hydrolase family 16, Agarivorans, cloning, expression

\section{서 론}

한천은 galactose와 galactopyranose의 중합체로[5] 홍조류 의 세포벽에서 유래하며 우뭇가사리(천초, Gelidium), 석무, 꼬 시래기 등을 이용하여 제조한다[8]. 한천 다당류는 친수성 고 분자로 콜로이드의 성질을 나타내며 낮은 농도로도 겔 형성능 이 있으며 $85^{\circ} \mathrm{C}$ 이하에서는 녹지 않아 식품산업, 향장품, 의약 산업의 안정제로 사용된다[8].

한천유래 올리고당의 다양한 생리적 활성이 보고되었으며 올리고당을 생산하는 방법으로는 산가수분해법과 효소분해 법이 보고되었다. 산가수분해법은 생산된 한천올리고당의 낮 은 기능성과 중화가 필요하여 처리과정에서의 환경오염 등의 문제가 있어 한천분해효소를 이용하는 것이 유용한 것으로 알려졌다[21]. 따라서 한천분해효소를 생산하는 균주의 탐색 과 재조합발현에 관한 연구가 많이 보고되어 왔다[15,16,19, 22]. 저자들도 한천분해세균으로 Agarivorans [19], Thalassomonas [15], Glaciecola [16]속 세균 등을 보고하였으며, Agarivorans sp. JA-1 유래의 B-agarase를 대장균과 고초균에서 재조합 발현시 켰고 한천을 분해하여 생성된 한천올리고당의 세포독성 없는 미백활성을 보고하였다[10,13].

한천 다당류에 대한 연구는 다당류의 기능과 다당류 생산에 관한 것이 주를 이루고 있다. 한천의 a-agarase 분해산물인 한 천올리고당(agarooligosaccharides)이나 $\beta$-agarase 분해산물 인 네오한천올리고당(neoagarooligosaccharides)의 보고된 기

*Corresponding author

Tel : +82-51-999-5624, Fax : +82-51-999-5636

E-mail : slee@silla.ac.kr
능성은 면역증진, 항암, 간보호, 항산화, 항균, probiotics, 미백, 보습 효과 등으로 고부가가치 기능성물질의 가능성이 매우 높아 많은 연구가 수행되어 왔다[12]. 한편 한천은 $40^{\circ} \mathrm{C}$ 이상에 서 sol 상태이고 일반적으로 효소활성은 sol 상태가 gel 상태에 비해 높으므로 $40^{\circ} \mathrm{C}$ 이상에서 활성이 높은 agarase를 탐색하 거나 돌연변이법으로 개선시키려는 노력이 행해졌다[12].

Agarivorans속 세균은 Gammaproteobacteria에 속하는 호 기성의 그람음성균으로 한천을 분해하는 능력이 있으며 표준 균주(type species)로 Agarivorans albus가 보고되어 있다[6]. 현 재까지 특성이 보고된 Agarivorans 속 세균의 agarase는 분자 량이 $100 \mathrm{kDa}$ 이상이었는데[6,9,13], 저자들은 $48 \mathrm{kDa}$ 의 새로 운 agarase를 확인하였다[14].

본 연구에서는 저자들이 이전 연구에서 한천분해효소 유 전자를 클로닝하여 보고한 Agarivorans sp. JA-1 [19] 균주에 서 새로운 한천분해효소 유전자를 분리하고 대장균에서 재 조합 발현시키고 정제를 수행한 후 파악된 효소의 특성을 조 사하였다.

\section{재료 및 방법}

\section{균주, 시약 및 배지}

새로운 $\beta$-agarase의 확보에 이용한 균주인 Agarivorans sp. JA-1은 제주도 해역에서 분리된 한천분해 세균이다[19]. 대장 균 세포(E. coli DH5a)를 유전자 클로닝을 위한 숙주로 사용하 였고 $\mathrm{LB}$ 배지 $(1 \%$ bacto tryptone, $0.5 \%$ yeast extract, $0.5 \%$ $\mathrm{NaCl})$ 와 $37^{\circ} \mathrm{C}$ 조건에서 배양하였다. 대장균 형질전환체의 선 별을 위해서는 ampicillin을 최종농도 $100 \mu \mathrm{g} / \mathrm{ml}$ 가 되게 첨가 
한 LB 한천배지를 사용하였다. 단백질의 발현을 위한 숙주로 E. coli BL21 (DE3)를 사용하였다. 제한효소, T4 polynucleotide kinase, DNA ligation kit ver. 2, Pyrobest DNA polymerase는 Takara Korea (Seoul, Korea)에서 구입하였다.

\section{유전자 확보 및 클로닝}

전반적인 클로닝실험은 Sambrook 등의 방법을 따라서 수 행하였다[20]. Agarivorans sp. JA-1의 총세포 DNA는 Wizard Genomic DNA Purification Kit (Promega, Madison, WI, USA)를 사용하여 추출하였고, 플라스미드 DNA는 Sambrook 등의 알칼리분해법을 이용하였다[20]. 새로운 $\beta$-agarase AgaJA3 유전자는 Agarivorans sp. JA-1의 총세포 DNA를 주형 으로 Pyrobest DNA polymerase (Takara Bio Inc., Otsu, Japan)를 이용하여 증폭하였고, Vibrio sp. PO-303 [2]의 $\beta$ -agarase D 유전자의 서열을 참고로 하여 제조한 프라이머인 A_sp-b-agaJA3-F (5'-ATGAAAGGATTCACTAAGCACCCA CTAC-3')와 A_sp-b-agaJA3-R (5'-CTACTGGAATTTAAAAC GTTGGTTGGTAC-3')가 사용되었다. 증폭된 1.4-kb DNA를 pGEM-T easy vector (Promega)에 연결시켜 pGEMTe-A_sp$\mathrm{b}$-agaJA3을 제조하였고, E. coli DH5a 세포를 형질전환시켰다. DNA의 염기서열 파악은 BioNex사(Seoul, Korea)에 의뢰하였 고, 서열분석은 DS_Gene ver. 1.5 program (Accelrys Inc., San Diego, CA, USA)을 이용하여 수행하였다.

\section{재조합 $\beta$-agarase AgaJA3의 발현과 정제}

$\beta$-Agarase AgaJA3 유전자를 대장균에서 발현시키기 위하 여 신호서열(signal sequence)이 제거된 성숙체(mature form) 를 암호화하는 유전자를 증폭하였다. pGEMTe-A_sp-b-agaJA3 를 주형으로 Pyrobest DNA polymerase (Takara Bio Inc., Otsu, Japan)를 이용하여 증폭하였고, A_sp-b-agaJA3E-F (5'CATATGGACTGGGATAATATCCCAATTCC-3' (inserted a $N d d$ site is underlined))와 A_sp-b-agaJA3E-R (5'-CTCGAG CTGGAATTTAAAACGTTGGTTGG-3' (inserted a Xhd site is underlined))가 프라이머로 사용되었다. 증폭된 $1.3-\mathrm{kb}$ DNA를 pGEM-T easy vector (Promega)에 연결시켜 pGEMTeA_sp-b-agaJA3E를 제조하였고, E. coli $\mathrm{DH} 5 \mathrm{a}$ 세포를 형질전환 시켰다. DNA의 염기서열 파악은 BioNex사(Seoul, Korea)에 의뢰하였고, 서열분석은 DS_Gene ver. 1.5 program (Accelrys Inc., San Diego, CA, USA)을 이용하여 수행하였다. pGEMTeA_sp-b-agaJA3E를 제한효소 Ndd과 Xhd으로 처리한 후 확보 한 1.3-kb의 DNA 단편을 대장균 발현벡터인 pTXB1 (New England BioLabs Inc., Beverly, MA, USA)에 연결시켜 발현 플라스미드인 pTXB1-A_sp-b-agaJA3E를 재조하였고, E. coli $\mathrm{DH} 5 \mathrm{a}$ 세포를 형질전환시켰다. pTXB1-A_sp-b-agaJA3E를 제 한효소 $N d \mathrm{~d}$ 과 $X \mathrm{hd}$ 으로 절단하여 1.3-kb의 $\beta$-Agarase $\mathrm{AgaJA3}$ 성숙체 유전자 단편을 확인하였다.
pTXB1-A_sp-b-agaJA3E로 발현숙주인 E. coli BL21 (DE3) 세포를 형질전환시켰고, 획득한 재조합체를 ampicillin이 첨가 된 $10 \mathrm{ml}$ 의 $\mathrm{LB}$ 배지로 $37^{\circ} \mathrm{C}$ 에서 12 시간 배양하였다. 배양액을 ampicillin이 첨가된 11 의 $\mathrm{LB}$ 배지로 $37^{\circ} \mathrm{C}$ 에서 3 시간 배양한 후, IPTG를 최종농도 $0.3 \mathrm{mM}$ 로 첨가하여 $\mathrm{T} 7$ promoter를 활성 화시켰다. IPTG를 첨가한 후 추가로 $30^{\circ} \mathrm{C}$ 에서 3시간 배양하였 고 원심분리(5,000× $g$, 5 분)로 세포를 수확하여 여기에 냉장한 $30 \mathrm{ml}$ 의 칼럼(column) 완충용액(20 mM Tris- $\mathrm{HCl}$ (pH 7.4), $0.5 \mathrm{M} \mathrm{NaCl}, 0.2 \%$ Triton X-100, $2 \mathrm{mM} \mathrm{EDTA}$ )을 첨가하였다. 초음파로 세포를 파괴한 후 원심분리(20,000× $g, 20$ 분)를 행하 여 상층액을 회수하였다. 이후 상층액을 미리 칼럼완충용액으 로 처리한 Chitin beads (New England BioLabs Inc.) $20 \mathrm{ml}$ 가 충진된 칼럼에 통과시키고 칼럼완충용액으로 세척한 후, 칼럼 완충용액에 최종농도 $30 \mathrm{mM}$ DTT가 첨가된 분리(cleavage) 완충용액으로 $4^{\circ} \mathrm{C}$ 에서 밤새 처리하였다. 칼럼완충용액 $50 \mathrm{ml}$ 로 단백질을 용출시켰다. 단백질의 함량은 BSA (bovine serum albumin)을 표준으로 BCA protein assay 용액(Pierce Biotechnology, Rockford, IL, USA)을 이용하여 측정하였다.

\section{SDS-PAGE}

정제된 단백질을 확인하기 위하여 Laemmli의 방법에 따라 $11 \%$ 의 polyacrylamide 겔을 이용하여 SDS-polyacrylamide gel electrophoresis (PAGE)를 수행하였다. 정제된 효소액에 Laemmli's sample buffer를 첨가하여 5분간 중탕가열한 후, 전기영동을 수행하였고 GelCode Blue Stain Reagent (Pierce Biotechnology)를 이용하여 단백질을 가시화하였다.

\section{효소의 활성측정}

Agarase 활성은 아가로스에서 생성된 환원당을 SomogyNelson법으로 정량하여 확인하였다[19]. 기질용액으로 $0.2 \%$ $(\mathrm{w} / \mathrm{v})$ 의 아가로스를 포함하는 활성완충용액 $(50 \mathrm{mM}$ Tris- $\mathrm{HCl}$ (pH 7.0), $300 \mathrm{mM} \mathrm{NaCl}, 1 \mathrm{mM} \mathrm{CaCl}_{2}$ )을 중탕가열한 후, $45^{\circ} \mathrm{C}$ 까지 냉각시켜 사용하였다. 기질용액 $1 \mathrm{ml}$ 에 재조합 AgaJA3 효소액 $0.5 \mathrm{ml}$ 를 첨가하여 $45^{\circ} \mathrm{C}$ 에서 30 분간 반응시키고, 반응 용액 $0.5 \mathrm{ml}$ 에 Somogy 시약 $\left(10 \% \mathrm{CuSO}_{4} 80 \mathrm{ml}, 1 \mathrm{~N} \mathrm{NaOH}\right.$ $100 \mathrm{ml}, \mathrm{Na}_{2} \mathrm{SO}_{4} 180 \mathrm{~g}, \mathrm{Na}_{2} \mathrm{HPO}_{4} \cdot 12 \mathrm{H}_{2} \mathrm{O} 71 \mathrm{~g}, \mathrm{C}_{4} \mathrm{H}_{4} \mathrm{O}_{6} \mathrm{KNa}$ $4 \mathrm{H}_{2} \mathrm{O} 40$ g / D.W. 1 l) $0.5 \mathrm{ml}$ 를 첨가하여 효소반응을 중지시 키고 10 분간 중탕가열하였다. 실온으로 냉각된 용액에 arseno-molybdate 시약 $2 \mathrm{ml}$ 를 첨가하고 원심분리(14,000× $\mathrm{g}$ 5 분)를 행한 후 상층액의 흡광도를 $550 \mathrm{~nm}$ 에서 측정하였다. 1 분당 $1 \mu \mathrm{mole}$ 의 galactose를 생산하는 한천분해 효소의 양을 1 unit로 정의하였고 galactose를 이용하여 표준적정곡선을 작 성하였다.

$\mathrm{pH}$ 에 따른 한천분해효소의 활성측정

$\mathrm{pH}$ 에 따른 한천분해효소의 활성은 $\mathrm{pH}$ 를 3.0 에서 10.0 까지 
변화시키며 측정하였다. 넓은 $\mathrm{pH}$ 범위에서 사용가능한 완충 용액인 $50 \mathrm{mM}$ GTA (3,3-dimethyl-glutaric acid, Tris (hydroxymethyl)-aminomethane, 2-amino-2-methyl-1,3-propanediol) 완충용액 $(300 \mathrm{mM} \mathrm{NaCl}, 1 \mathrm{mM} \mathrm{CaCl}$ )을 이용하여 $\mathrm{pH}$ 3 10에서의 활성측정도 수행하였다.

\section{반응온도에 따른 한천분해 효소의 활성측정}

기질용액으로 $0.2 \%(\mathrm{w} / \mathrm{v})$ 의 아가로스를 포함하는 활성완 충용액(50 mM GTA-HCl (pH 5.0), $300 \mathrm{mM} \mathrm{NaCl}, 1 \mathrm{mM}$ $\mathrm{CaCl}_{2}$ )을 중탕가열한 후, $25 \sim 60^{\circ} \mathrm{C}$ 의 온도별로 냉각시켜 이용 하였다. 기질용액 $1.0 \mathrm{ml}$ 에 효소액 $0.5 \mathrm{ml}$ 를 첨가하여 각 온도 에서 30 분간 반응시킨 후 효소활성을 측정하였다[22].

\section{한천분해 효소의 열안정성 측정}

기질용액으로 $0.2 \%(\mathrm{w} / \mathrm{v})$ 의 아가로스를 포함하는 활성완 충용액(50 mM GTA-HCl (pH 5.0), $300 \mathrm{mM} \mathrm{NaCl}, 1 \mathrm{mM}$ $\mathrm{CaCl}_{2}$ )을 중탕가열한 후, $25 \sim 60^{\circ} \mathrm{C}$ 의 온도별로 냉각시켜 이용 하였다. 효소액 $0.5 \mathrm{ml}$ 를 각 온도별로 0.5 시간, 1 시간, 1.5 시간, 2시간 열처리한 후, 기질용액 $1.0 \mathrm{ml}$ 를 첨가하여 각 온도에서 30 분간 반응시킨 후 효소활성을 측정하였다. 측정된 효소활성 은 열처리전의 효소활성과 비교하였다.

\section{한천 가수분해산물의 thin-layer chromatography (TLC)} 분석

효소액을 이용한 아가로스 분해산물은 TLC로 분석하였다.
기질용액으로 $0.2 \%(\mathrm{w} / \mathrm{v})$ 의 아가로스를 포함하는 활성완충 용액(50 mM GTA-HCl (pH 5.0), $300 \mathrm{mM} \mathrm{NaCl}, 1$ mM CaCl 2 ) 을 중탕가열한 후 $40^{\circ} \mathrm{C}$ 까지 냉각시켜 사용하였다. 기질용액 $1 \mathrm{ml}$ 에 효소액 $0.5 \mathrm{ml}$ 를 첨가하여 $40^{\circ} \mathrm{C}$ 에서 24 그리고 48 시간 반응시킨 후, Silica gel 60 TLC plate (Merck, Darmstadt, Germany)을 이용하여 분해산물의 분석을 수행하였다[4,7]. 아 가로스 분해산물을 n-butanol/acetic acid/ $\mathrm{H}_{2} \mathrm{O} \quad(2 / 1 / 1$ $(\mathrm{v} / \mathrm{v} / \mathrm{v}))$ 를 이용하여 전개한 후 건조시켰고 표면에 $10 \%(\mathrm{v} / \mathrm{v})$ $\mathrm{H}_{2} \mathrm{SO}_{4}$ 를 뿌린 후 다시 건조시켰으며 이후 $80^{\circ} \mathrm{C}$ 에서 가시화시 켰다. 표준물질로 neoagarohexaose (Sigma, USA)와 neoagarotetraose (V-Labs Inc. St. Covington, LA, USA), galactose (ACROS, USA)를 사용하였다.

\section{결과 및 고찰}

\section{Agarivorans sp. JA-1의 $\beta$-agarase agaJA3 유전자 클로닝}

신규 agarase 유전자를 Agarivorans sp. JA-1 균주에서 확보 하고 염기서열을 결정하였다. 결정된 염기서열을 분석한 결 과, 신규 agarase 유전자는 GC 함량이 $44.13 \%$ 이며 $1362 \mathrm{bp}$ 의 길이였고 ATG로 시작되어 TAG로 끝나는 구조를 나타냈다 (Fig. 1). 이는 453아미노산으로 구성된 분자량 49,830 dalton $(\mathrm{Da})$ 의 단백질을 합성할 수 있다(Fig. 1). 염기서열은 Vibrio sp. PO-303의 $\beta$-agarase agaD 유전자(GenBank: AB221476)와 97\%[3] 그리고 Pseudoalteromonas sp. CY24의 $\beta$-agarase agaA

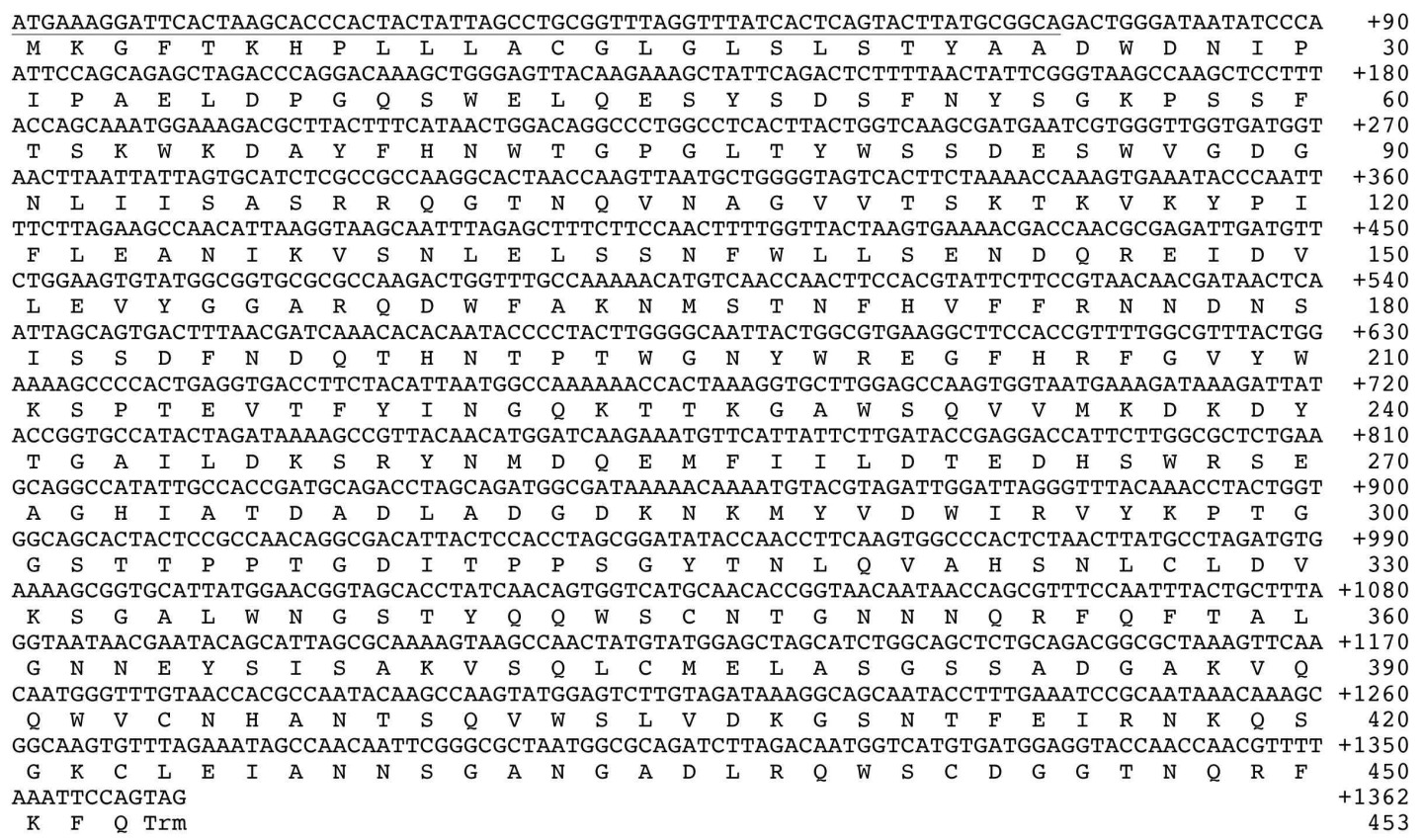

Fig. 1. Nucleotide sequence of the $\beta$-agarase agaJA3 gene of Agarivorans sp. JA-1 and deduced amino acid sequence of the enzyme. The nucleotide sequence of the $\beta$-agarase gene is shown. The deduced amino acid sequence of the gene product is indicated by the single letter codes under the nucleotide sequence. The putative signal peptide sequence is underlined. 
유전자(AY150179)와 98\%의 유사도를 보였다[17].

신규 agarase의 아미노산 서열은 Vibrio sp. PO-303의 $\beta$ -agarase AgaD (BAF34350)와 98\%[3], Pseudoalteromonas sp. CY24의 $\beta$-agarase AgaA와 99\%[17] 유사한 것으로 나타났다. 또한, Agarivorans albus YKW-34의 GH-16 $\beta$-agarase와 88\%의 유사성을 보였다. 현재까지 보고된 $\beta$-agarase는 서열의 유사 성을 기준으로 glycosyl hydlorase (GH) family 즉, GH-16, -50, -86, -118의 4그룹으로 나눌 수 있다(http://www.cazy.org/). 아미노산 및 염기서열 유사도가 $97 \%$ 이상인 2 개의 B-agarase는 GH-16에 속하여 본 연구에서 확보한 신규 agarase 유전자를 GH-16에 속하는 것으로 분류하고 $\beta$-agarase agaJA3 유전자로 명명하였다. 본 연구를 통하여 저자들이 제 주도 연안에서 분리한 Agarivorans sp. JA-1 [19] 균주에서 GH-50 [13], GH-118 [14] 외에 GH-16에 속하는 새로운 $\beta$ -agarase 유전자를 확보하였다.

\section{재조합 $\beta$-agarase agaJA3의 발현과 정제}

SignalP 4.0 Server (http://www.cbs.dtu.dk/services/ SignalP/)를 이용하여 $\beta$-agarase agaJA3 유전자의 신호서열 을 조사한 결과, $\mathrm{N}$ 말단에서부터 24 개의 아미노산이 신호서열 로 나타나 이를 제외한 429개의 아미노산 서열을 재조합 발현 시켰다. E. coli BL21 (DE3) 숙주에서 pTXB1-A_sp-3-agaJA3E 플라스미드는 높은 수준의 재조합 $\beta$-agarase agaJA3을 생산 하였다(Fig. 2).

재조합 $\beta$-agarase agaJA3는 affinity chromatography를 거 쳐 85 배 농축되었으며 비활성(specific activity)은 $67.6 \mathrm{U} / \mathrm{mg}$

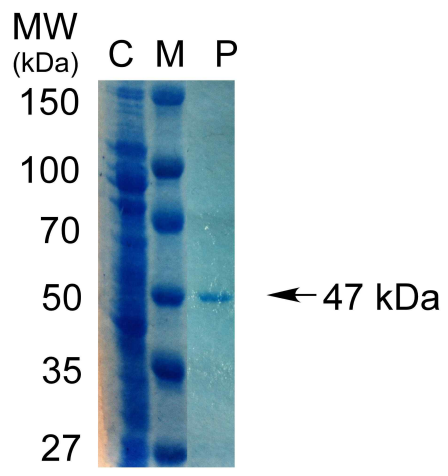

Fig. 2. SDS-PAGE of recombinant $\beta$-agarase AgaJA3 from $E$. coli cells harboring pTXB1-A_sp-b-agaJA3E. Lane M, size marker; lane $\mathrm{C}$, cell-free extract; lane $\mathrm{P}$, purified enzyme by affinity chromatography. Arrow indicates the position of recombinant $\beta$-agarase AgaJA3.
이었고 최종 $15 \%$ 의 수율을 보였다(Table 1). 정제된 효소의 SDS-PAGE에서 분자량 $47 \mathrm{kDa}$ 의 단일밴드를 보이는 것으로 나타났고(Fig. 2), 이는 염기서열을 토대로 추산한 것과 일치하 였다.

\section{$\mathrm{pH}$ 와 온도에 따른 효소활성과 안정성}

각 $\mathrm{pH}$ 에서의 $\beta$-agarase agaJA3의 활성을 Fig. 3에 나타냈 다. 사용한 $\mathrm{pH}$ 중에서 $\mathrm{pH} 5.0$ 에서 최고활성이 나타났다. 또한, $50 \mathrm{mM} \mathrm{GTA}-\mathrm{HCl}$ 완충용액으로 활성을 측정하였을 때 $\mathrm{pH}$ 5.0 과 6.0 의 범위에서 한천분해 상대활성이 $99 \%$ 이상 유지되 어 좁은 범위의 $\mathrm{pH}$ 에서 활성이 유지되는 것으로 파악되었고, $\mathrm{pH} 7.0$ 에서는 $78 \%$ 정도의 상대활성을 나타냈으므로 중성과 약산성 범위에서 높은 활성을 보였다. 따라서 $\mathrm{pH} 5.0$ 이 최적 $\mathrm{pH}$ 로 판단되었다. 동일한 균주인 Agarivorans sp. JA-1에서 파 악한 다른 한천분해효소의 최적 $\mathrm{pH}$ 는 GH-50 $\beta$-agarase 효소 가 $\mathrm{pH}$ 8.0이었고[19], $\mathrm{GH}-118$-agarase 효소는 $\mathrm{pH}$ 7.0이었 다[14]. 그리고 $\beta$-agarase agaJA3와 아미노산 서열의 유사도가 높은 Vibrio sp. PO-303의 $\beta$-agarase $\mathrm{AgaD}$ 의 최적 $\mathrm{pH}$ 는 7.5였 으며[3], Pseudoalteromonas sp. CY24의 $\beta$-agarase AgaA는 $\mathrm{pH}$ 6.5 에서 최대활성을 보였다[17].

최적 $\mathrm{pH}$ 인 $\mathrm{pH} 5.0$ 의 $50 \mathrm{mM}$ GTA-HCl 완충용액을 사용하 여 파악한 각 온도에서의 $\beta$-agarase agaJA3의 활성을 Fig. $4 \mathrm{~A}$ 에 나타냈다. 최고의 활성을 나타낸 $40^{\circ} \mathrm{C}$ 의 반응온도에서 나 타난 효소활성인 $67.6 \mathrm{U} / \mathrm{mg}$ 을 $100 \%$ 로 하였을 때, $30^{\circ} \mathrm{C}$ 에서 $92 \%, 50^{\circ} \mathrm{C}$ 에서 $62 \%, 60^{\circ} \mathrm{C}$ 에서 $38 \%$ 의 상대활성을 나타내는

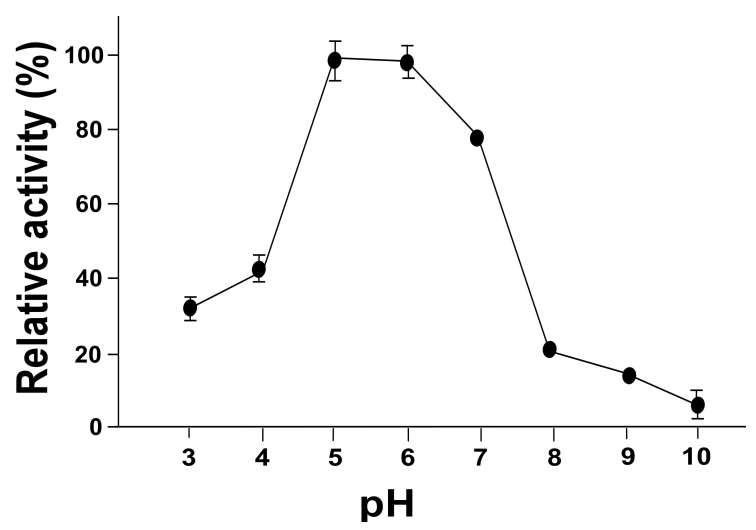

Fig. 3. Effects of $\mathrm{pH}$ on the activity of recombinant $\beta$-agarase AgaJA3. The buffers used were $50 \mathrm{mM}$ GTA- $\mathrm{HCl}$ buffer $(\mathrm{pH} 3.0 \sim 10.0)$. The values are shown as percentages of enzyme activity (100\%) observed at $\mathrm{pH} 5.0$.

Table 1. Purification of $\beta$-agarase AgaJA3 from E. coli cells harboring pTXB1-Asp- $\beta$-agaJA3E

\begin{tabular}{lcccc}
\hline Purification step & Total protein $(\mathrm{mg} / \mathrm{l})$ & Total activity $(\mathrm{U})$ & Specific activity $(\mathrm{U} / \mathrm{mg})$ & Yield $(\%)$ \\
\hline Cell-free extract & 677.8 & 542.2 & 0.8 & 100 \\
Affinity chromatography & 1.2 & 81.1 & 67.6 & 15 \\
\hline
\end{tabular}


A

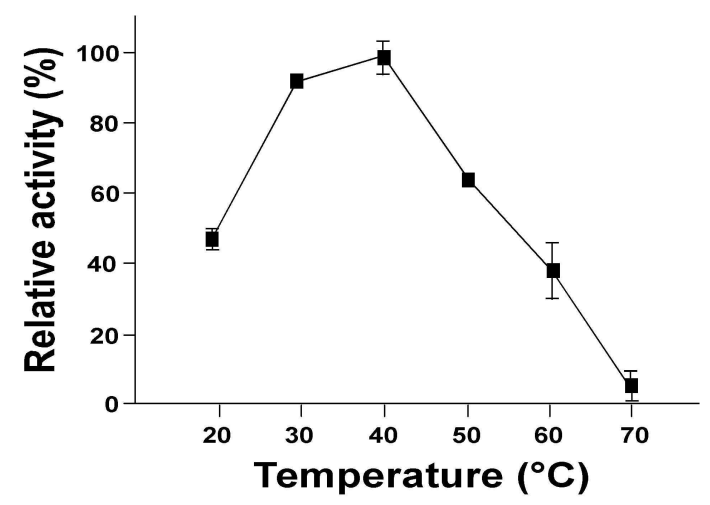

B

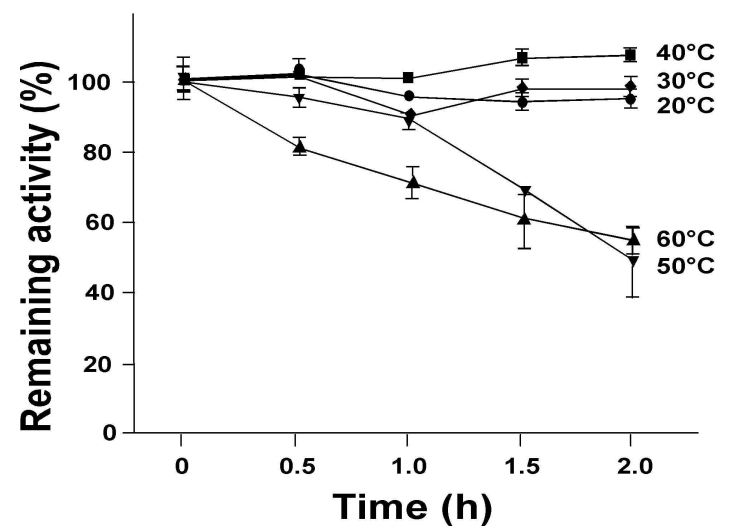

Fig. 4. Effect of temperature on activity (A) and stability (B) of recombinant $\beta$-agarase AgaJA3 in $50 \mathrm{mM}$ GTA-HCl buffer ( $\mathrm{pH} 5.0$ ). (A) The reaction was performed at 20, $30,40,50,60$, or $70^{\circ} \mathrm{C}$ with $1 \mathrm{ml}$ of $0.2 \%$ agar in $50 \mathrm{mM}$ GTA-HCl (pH 5.0) buffer and $0.5 \mathrm{ml}$ of enzyme solution for $20 \mathrm{~min}$. Values are shown as percentages of enzyme activity $(100 \%)$ observed at $40^{\circ} \mathrm{C}$. (B) The enzyme $(0.2$ unit $/ \mathrm{ml}$ ) was preincubated at the indicated temperatures for 30,60, 90 and 120 minute with $0.2 \%$ agar in $50 \mathrm{mM}$ GTA-HCl (pH 5.0) buffer. Samples were applied to measure residual under the standard conditions of enzyme assay. The values are percentages of enzyme activity $(100 \%)$ observed at pH 5.0 without heating.

것으로 파악되었다(Fig. 4A). 이러한 결과로 $\beta$-agarase agaJA3 는 한천분해효소는 $40^{\circ} \mathrm{C}$ 에서 활성이 높은 효소라는 것을 알 수 있었다. 동일한 균주인 Agarivorans sp. JA-1에서 파악한 다른 한천분해효소의 최적 온도는 GH-50 $\beta$-agarase 효소가 $40^{\circ} \mathrm{C}$ 였고[19], GH-118 $\beta$-agarase 효소는 $35^{\circ} \mathrm{C}$ 였다[14]. 그리 고 $\beta$-agarase agaJA3와 아미노산 서열의 유사도가 높은 Vibrio sp. PO-303의 $\beta$-agarase AgaD와[3] Pseudoalteromonas sp. $\mathrm{CY} 24$ 의 $\beta$-agarase AgaA[17] 모두 $40^{\circ} \mathrm{C}$ 에서 최대활성을 보여 $\beta$-agarase agaJA3와 동일하였다.

Agarivorans sp. JA-1 유래의 $\beta$-agarase agaJA3의 열안정성

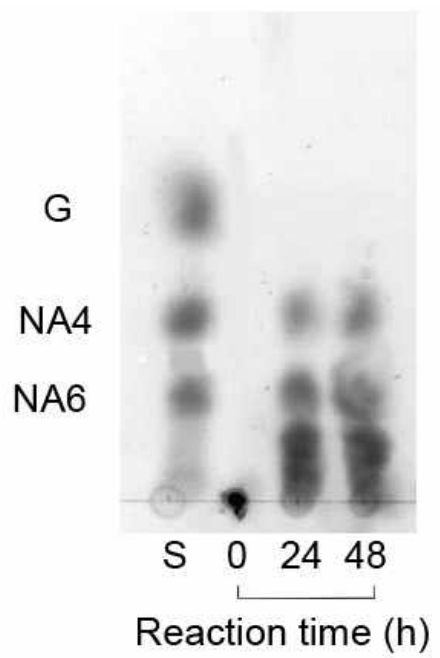

Fig. 5. TLC analysis of the hydrolyzed products of agarose by $\beta$-agarase AgaJA3. The reaction was carried out at $40^{\circ} \mathrm{C}$ in $50 \mathrm{mM}$ GTA-HCl (pH 5.0) buffer with enzyme solution for 24 and $48 \mathrm{~h}$. The reaction mixture was developed by TLC. Gal, D-galactose; NA4, neoagarotetraose; NA6, neoagarohexaose.

을 Fig. $4 \mathrm{~B}$ 에 나타내었다. $40^{\circ} \mathrm{C}$ 에서는 $1,1.5,2$ 시간 정도의 열처 리를 하여도 열처리하지 않은 효소가 나타내는 활성의 $99 \%$ 이상을 유지하여 열안정성을 보였지만, $60^{\circ} \mathrm{C}$ 에서는 30 분간 열 처리를 행했을 때 열처리하지 않은 효소 활성의 $81 \%$ 를 보였고 2 시간이 지나면서 $60 \%$ 수준으로 저하되어 열안정성을 보이지 않았다. 따라서 $\beta$-agarase agaJA3는 내열성은 높지 않은 것으 로 판단되었다.

고체상태인 한천이나 아가로스를 가열하여 녹인 용액은 $40^{\circ} \mathrm{C}$ 이하의 온도에서는 고체가 되는데, Agarivorans sp. JA-1 유래 의 $\beta$-agarase agaJA3는 $40^{\circ} \mathrm{C}$ 이상의 온도에서도 높은 활성을 나타내므로 기질이 액체상태의 반응조건에서 한천올리고당 을 생산하는 반응을 수행할 수 있어 효율적인 한천올리고당 생산공정의 개발이 가능할 것으로 기대된다.

\section{효소분해산물의 TLC 분석}

재조합 발현 후 정제된 Agarivorans sp. JA-1 유래의 $\beta$ -agarase agaJA3 효소액에 아가로스를 기질로 첨가하여 시간 별로 반응시킨 후 TLC로 분석한 결과를 Fig. 5에 표시하였다. a-agarase는 기질인 한천이나 아가로스에서 agaropentose 혹 은 agarotriose를 생성할 수 있지만 $\beta$-agarase는 neoagarohexaose (NA6), neoagarotetraose (NA4) 그리고 neoagarobiose (NA2)를 생성할 수 있다[1,18,23]. $\beta$-agarase agaJA3의 반응초기에 다양한 크기의 한천올리고당이 형성되 어 무작위적으로 기질을 endo-type 형식으로 분해하는 것으 로 파악되었다[17]. 0시간에는 아가로스가 분해되지 않아 TLC 에서 이동하지 않은 것을 알 수 있으며 반응 24시간에는 아가 
로스가 거의 분해되어 NA6 $(24.8 \%)$ 와 NA4 $(15.7 \%)$ 가 주로 생산되었다. 48시간도 24시간과 유사하였다. 따라서 Agarivorans sp. JA-1 유래의 $\beta$-agarase agaJA3가 $\beta$-agarase임 을 확인할 수 있었다(Fig. 5). $\beta$-agarase agaJA3와 아미노산 서열의 유사도가 높은 Pseudoalteromonas sp. CY24의 $\beta$ -agarase AgaA[17]은 아가로스 기질에서 최종적으로 NA4와 $\mathrm{NA6}$ 를 주산물로 형성하였으며 Vibrio sp. PO-303의 $\beta$ -agarase AgaD[3]는 NA4를 주산물로 NA6와 NA2가 일부 형 성되었다.

본 연구에서 분리하고 재조합 발현시킨 Agarivorans sp. JA-1 유래의 $\beta$-agarase agaJA3는 보습과 미백기능을 나타내는 NA4 등의 한천올리고당의 소재물질의 생산에 유용하게 이용 할 수 있을 것이다[10,11,13].

\section{감사의 글}

이 논문은 해양수산부 주관 마린바이오21사업 해양 - 극한 생물 분자유전체연구단의 지원을 받아 수행되었습니다.

\section{References}

1. Araki, T., Lu, Z. and Morishita, T. 1998. Optimization of parameters for isolation of protoplasts from Gracilaria verrucosa (Rhodophyta). J. Mar. Biotechnol. 6, 193-197.

2. Dong, J., Hashikawa, S., Konishi, T., Tamaru, Y. and Araki, T. 2006. Cloning of the novel gene encoding $\beta$-agarase $C$ from a marine bacterium, Vibrio sp. strain PO-303, and characterization of the gene product. Appl. Environ. Microbiol. 72, 6399-6401.

3. Dong, J., Tamaru, Y. and Araki, T. 2007. Molecular cloning, expression, and characterization of a $\beta$-agarase gene agaD, from a marine bacterium, Vibrio sp. strain PO303. Biosci. Biotechnol. Biochem 71, 38-46.

4. Duckworth, M. and Yaphe, W. 1970. Thin-layer chromatographic analysis of enzymic hydrolysate of agar. $J$. Chromatogr. 49, 482-487.

5. Duckworth, M. and Yaphe, W. 1971. Structure of agar. I. Fractionation of a complex mixture of polysaccharides. Carbohyd Res. 16, 189-197.

6. Fu, X. T., Pan, C. H., Lin, H. and Kim, S. M. 2009. Gene cloning, expression, and characterization of a $\beta$-agarase, AgaB34, from Agarivorans albus YKW-34. J. Microbiol. Biotechnol. 19, 257-264.

7. Groleau D. and Yaphe, W. 1977. Enzymatic hydrolysis of agar, purification and characterization of $\beta$-neoagarotetraose hydrolase from Pseudomonas atlantica. Can. J. Microbiol. 23, 672-679.

8. http://www.miryangagaragar.com/main.php

9. Hu, Z., Lin, B.-K., Xu, Y., Zhong, M. Q. and Liu, G.-M. 2009. Production and purification of agarase from a marine agarolytic bacterium Agarivorans sp. HZ105. J. Appl. Microbiol. 106, 181-190.
10. Jang, M.-K., Lee, D.-G., Kim, N.-Y., Yu, K.-H., Jang, H. J., Lee, S. W., Lee, Y. J. and Lee, S.-H. 2009. Purification and characterization of neoagarotetraose from hydrolyzed agar. J. Microbiol. Biotechnol. 19, 1197-1200.

11. Kobayashi, R., Takisada, M., Suzuki, T., Kirimura, K. and Usami, S. 1997. Neoagarobiose as a novel moisturizer with whitening effect. Biosci. Biotechnol. Biochem 61, 162-163.

12. Lee, D.-G. and Lee, S.-H. 2012. The classification, origin, collection, determination of activity, purification, production, and application of agarases. J. Life. Sci. 22, 266-280.

13. Lee, D.-G., Park, G.-T., Kim, N. Y., Lee, E.-J., Jang, M. K., Shin, Y. G., Park, G.-S., Kim, T.-M., Lee, J.-H., Lee, J.-H., Kim, S.-J. and Lee, S.-H. 2006. Cloning, expression, and characterization of a glycoside hydrolase family 50 ß-agarase from marine Agarivorans isolate. Biotechnol. Lett. 28, 19251932.

14. Lee, D.-G., Jeon, M. J. and Lee, S.-H. 2012. Cloning, expression, and characterization of a glycoside hydrolase family 118 -agarase from Agarivorans sp. JA-1. J. Micobiol. Biotechnol. in progress.

15. Lee, D.-G., Kim, N. Y., Jang, M. K. and Lee, S.-H. 2007. Isolation and characterization of a marine bacterium Thalassomonas sp. SL-5 producing $\beta$-agarase. J. Life. Sci. 17, 70-75.

16. Lee, D.-G., Lee, O.-H., Jang, H. J., Jang, M.-K., Yoo, K. H. and Lee, S.-H. 2008. Isolation and characterization of a marine derived bacterium Glaciecola sp. SL-12 producing $\beta$ agarase. J. Life Sci. 18, 58-62.

17. Lu, X., Chu, Y., Wu, Q., Gu, Y., Han, F. and Yu, W. 2009. Cloning, expression and characterization of a new agarase-encoding gene from marine Pseudoalteromonas sp. Biotechnol. Lett. 10, 1565-1570.

18. Ohta, Y., Hatada, Y., Miyazaki, M., Nogi, Y., Ito, S. and Horikoshi, K. 2005. Purification and characterization of a novel alpha-agarase from a Glaciecola sp. Curr. Microbiol. 50, 212-216.

19. Park, G. T., Lee, D. G., Kim, N. Y., Lee, E. J., Jung, J. G., Lee, J. H., Heo, M. S. and Lee, S. H. 2005. Isolation and characterization of a marine bacterium producing thermotolerant agarase. J. Life Sci. 15, 884-888.

20. Sambrook, J., Fritsch, E. and Maniatis, T. 1989. Molecular cloning: A laboratory manual. 2nd eds., pp. 23-38. Cold Spring Harbor Laboratory Press, Cold Spring Harbor, NY, USA.

21. Schafer, H. 2007. Isolation of Methylophaga spp. from marine dimethylsulfide-degrading enrichment cultures and identification of polypeptides induced during growth on dimethylsulfide. Appl. Environ. Microbiol. 73, 2580-2591.

22. Suzuki, H., Sawai, Y., Suzuki, T. and Kawai, K. 2002. Purification and characterization of an extracellular a -neoagarooligosaccharide hydrolase from Bacillus sp. MK03. J. Biosci. Bioeng. 93, 456-463.

23. Yoshizawa, Y., Ametani, A., Tsunehiro, J., Nomura, K., Itoh, M., Fukui F. and Kaminogawa, S. 1995. Macrophage stimulation activity of the polysaccharide fraction from a marine alga (Porphyra yezoensis), structure-function relationships and improved solubility. Biosci. Biotechnol. Biochem 59, 1933-1939. 
초록 : Agarivorans sp. JA-1 유래 신규 GH-16 $\beta$-agarase의 클로닝, 발현 및 특성

전명제·김아람 · 이동근 · 이상현*

(신라대학교 의생명과학대학 제약공학과)

이전 연구에서 저자들이 Glycoside hydrolase family 50 (GH-50)과 GH-118 $\beta$-agarase들의 발현과 특성을 보고 한 Agarivorans sp. JA-1 균주로부터 신규의 GH-16 $\beta$-agarase를 보고하고자 한다. 본 유전자는 1,362 염기쌍으로 구성되어 있으며, 453 아미노산 잔기로 구성된 $49,830 \mathrm{Da}$ 의 단백질을 암호화한다. 본 효소는 Pseudoalteromonas sp. CY24 유래의 GH-16 ß-agarase와 98\%의 염기서열 상동성과 99\%의 아미노산서열 상동성을 나타냈다. 신호서 열을 제외한 429 아미노산으로 구성된 성숙단백 질에 해당하는 유전자를 E. coli BL21 (DE3) 세포에서 재조합 발현 시킨 후, 친화성 크로마토그래피로 효소를 정제하였다. 정제된 효소는 $40^{\circ} \mathrm{C}$ 와 $\mathrm{pH} 5.0$ 에서 $67.6 \mathrm{U} / \mathrm{mg}$ 의 최적 활 성을 보였다. 아가로스를 기질로 한 효소분해산물의 박막크로마토그래피 분석결과, neoagarohexaose와 neoagarotetraose가 주산물로 생산되는 것을 알 수 있었다. 본 효소는 기능성 한천올리고당의 산업적 생산에 활용 가능할 것으로 기대된다. 